Article

\title{
Community-Based Tourism through Food: A Proposal of Sustainable Tourism Indicators for Isolated and Rural Destinations in Mexico
}

\author{
Mariana Sosa (D), Silvia Aulet (D) and Lluis Mundet*(D) \\ Faculty of Tourism, University of Girona, Plaça Ferrater Móra 1, 17004 Girona, Spain; \\ marianam.sosat@gmail.com (M.S.); silvia.aulet@udg.edu (S.A.) \\ * Correspondence: 1luis.mundet@udg.edu; Tel.: +34-670-229-200
}

Citation: Sosa, M.; Aulet, S.; Mundet, L. Community-Based Tourism through Food: A Proposal of Sustainable Tourism Indicators for Isolated and Rural Destinations in Mexico. Sustainability 2021, 13, 6693. https://doi.org/10.3390/su13126693

Academic Editors: Oliver Meixner, Petra Riefler and Karin Schanes

Received: 28 April 2021

Accepted: 9 June 2021

Published: 12 June 2021

Publisher's Note: MDPI stays neutral with regard to jurisdictional claims in published maps and institutional affiliations.

Copyright: (c) 2021 by the authors. Licensee MDPI, Basel, Switzerland. This article is an open access article distributed under the terms and conditions of the Creative Commons Attribution (CC BY) license (https:/ / creativecommons.org/licenses/by/ $4.0 /)$.
Abstract: Purpose: this article presents a conceptual framework for examining community tourism as a sustainable livelihood through food tourism, considering the significant increase in communitybased tourism in Mexico and the impact this activity has on rural and vulnerable destinations. The main aim of this research is to generate a proposal for a set of sustainable tourism indicators for rural and isolated communities through food strategies geared towards tourism development. Methodology: this information can then be used to generate a first list of indicators for creating and evaluating community tourism proposals in a region. Said theoretical list includes four dimensions (socio-cultural, environmental, tourist, and economic), which comprise 27 indicators in total. Findings: the results, validated by different participants related to the tourism sector, show that a lack of information for quantifying indicators is one of the main limitations when evaluating a vulnerable destination and that participation by the private sector and public administrations will be essential in generating these data. Approach: this research will therefore contribute to the development of new action strategies that allow not only the strengthening of the current localized agri-food systems, but also the revaluation of forgotten food systems.

Keywords: food tourism; community-based tourism; sustainable development; community engagement; rural development; food heritage

\section{Introduction}

Tourism has often been deemed a detrimental activity for local communities and sustainable development [1]. Consequently, a better understanding of how the agri-food system fits within ecological and social systems is required [2]. In this regard, local community participation in the fields of disaster preparedness and mitigation has been acknowledged as a key element by governments and NGOs, even in relation to disaster response and recovery after a natural disaster [3]. Furthermore, several authors adopt a poststructuralist perspective to argue how certain types of "tourism development" display traits that promote local economic sustainability and greater community equality, in addition to contributing to the reduction and recovery of disaster risk and poverty [4]. A review of the literature reveals that community-based tourism is considered to serve as a tool for locally led development, and effective disaster risk reduction and recovery.

The aim of the present study is to explore the connection between the development of community-based tourism and food as drivers for sustainable tourism development. To explore the connection, a proposal of indicators to measure the role food has in this development will be provided after reviewing the existing literature on sustainable tourism indicators and approaches to gastronomic tourism. The indicators are considered in light of the following four criteria: the relevance of STIs to Sustainable Development Goals, the role of local community participation as an important element of sustainability, the stakeholders involved, and the importance of local gastronomy in rural destinations. Therefore, this 
study seeks to highlight the literature on community tourism, contribute to the formation of existing sustainable tourism indicators, and offer recommendations for the development of indicators with which to measure the role food plays in sustainable tourism in rural and isolated destinations. Therefore, the main outcome of this work is the proposal of a system of indicators. The system is divided into four dimensions, with key areas for measuring local sustainability in vulnerable communities related to the destination's gastronomy. Traditional gastronomy and ethnic food are tools for the construction of nations and the emergence of collective social identities, which empower and provide an opportunity for sustainable livelihood in vulnerable and marginalized communities. Community-based tourism can help promote food-related values among visitors and improve the livelihoods of locals. Thus, CBT is considered to be a negotiation between the sectors specifically involved in gastronomy, aimed at achieving a balance between the preservation of natural and cultural heritage, economic viability, and social equity [5].

The paper is structured as follows. In the first section, the theoretical framework related to gastronomic tourism, culinary heritage within communities, and community development through community tourism is presented. Secondly, in the methodology section, authors present the tools used to create community tourism indicators aimed at developing sustainable strategies through local gastronomy. In the discussion of the results, the indicators selected are developed, highlighting the connection with food and supporting the results with data from some case studies.

\section{Community and Gastronomy, the Perfect Match for Sustainable Development}

Tourism has the potential to contribute, directly or indirectly, to each of the UN's 17 SDGs' [6], and has been identified as playing a particularly important role in the pursuit of goals 2 (Zero Hunger), 8 (Inclusive and sustainable economic growth), 12 (Sustainable consumption and production), and 14 (Sustainable use of oceans and marine resources) [6]. It can be argued that sustainable human development consists of human encouragement and personal self-promotion in a specific societal and community context in which personal aspirations, capacities, means, and possibilities may be achieved and contribute to improving society and the quality of life of a person and those around them [7].

The approach that UNWTO and UNDP [6] have adopted towards SDGs has been criticized for its emphasis on measurement and surveillance, reflecting the application of scientific and utilitarian economic approaches in the service of resource utilization and economic development [8]. Development can be referred to as the process of creating opportunities, and "sustainable development" as the process that promotes adaptive competencies whilst creating opportunities [9]. In this context, culture and tourism are tools that can be used to boost quality of life [10]. Some philosophers have also highlighted the importance of culture, mentality, attitude, and values in achieving a more sustainable society that should be based on a change of consciousness [11].

As mentioned in the SDG objectives, food sustainability is the key to promoting agriculture development, food safety, nutrition, sustainable food production, and biodiversity conservation [12]. Implementing sustainable gastronomy contributes to fulfilling objective number two of the Sustainable Development Goals: a \#ZeroHunger world is possible by 2030 . It is important to understand the concept of food sovereignty when aiming to achieve sustainable development based on food production. With respect to this, there is the need for a better understanding of the role played by the agri-food system in ecological and social systems [13]. A lack of food not only contributes to the malnutrition of the population but, on a wider scale, is also the main slowing element of rural territories, resulting in hunger, poverty, and unemployment [14]. Gastronomical traditions reflect a variety of socio-ecological conditions that are inherent in definitions of place and ethnic identity [4].

Food sovereignty was defined at the NGO/CSO Forum in 2002 as "the right of peoples, communities, and countries to define their own agricultural, labor, fisheries, food and land policies so that they are ecologically, socially, economically and culturally appropriate 
for their unique circumstances. This includes the right to food and food production, which means that all peoples have the right to safe, nutritious and culturally significant food, resources for food production and the ability to maintain themselves and their societies" [15].

Food sovereignty aims to encourage and support quick individual and community access and control over resources (land, seeds, credit or economic support from the government, etc.), respecting the rights of use of indigenous and native communities, with special emphasis on access to resources by women [16]. Consequently, it has been proposed to assess the benefits of small-scale agriculture, which accounts for the production of $39 \%$ of basic foods (mainly corn, beans, and fruits), generates $63.4 \%$ of agricultural employment, is a supplier of agribusiness chains (beer, tobacco, sugar), and protects agricultural biodiversity [17].

Indeed, food, cuisine, and culinary traditions are among the most basic elements of culture [4]. As regards the heritage-ilization of products and dishes, these include those expressions of regional or local cuisine that can demonstrate a strong connection with a specific territory over a long period [18]; that is, they are rooted in local history, and are associated with a set of specific knowledge and practices [19]. Institutions such as UNESCO have defined gastronomy as the use and representation of techniques that are transmitted from generation to generation, instilling a sense of identity and continuity in a community, thus contributing to the promotion of respect and human creativity. This can mainly be seen in agricultural activities, which are found in tourism as an activity that can complement income generation [20].

Therefore, gastronomy has become a catalyst for inclusion and sustainable development of tourist destinations [21,22] which fosters planning, sustainability, and inclusion of the population [23], as well as a pleasant experience that defines individual and social well-being [24]. Culinary tourism is a growing element of cultural tourism because it helps countries and regions define what they are and what it means to be from there $[4,25]$. Also, regional cuisines enhance a destination's image abroad, and many locations therefore promote their culinary heritage as a means of creating a place-bound image and firming up their own cultural identities [4], using it as a tool for socio-economic development through tourism [26].

Taking Mexico as an example, food has long played both a divisive and uniting role in the process of national development. In colonial Mexico, it was an important marker of social and political status [4]. Other authors have defined it as a process in rural development that improves the quality of life and well-being of people in working-class areas [27]. Rural communities can benefit from the marketing of local products [28]; followed by food traditions, they involve many elements of heritage, including indigenous peoples and their folklore, living conditions, celebrations and rituals, religious rites, interpersonal relationships, family habits, recipes, and common kitchen utensils $[29,30]$.

It is also worth mentioning "foodways" - or social and economic cultural practices related to food production and consumption [31,32]. Due to human development, the tourism and agriculture industries are local actions that affect economic activity and sales as a result of community business [20]. This results in the acquisition of human capital, understood as "the acquired knowledge and skills that the individual contributes to an activity" [33]. This allows for cooperation and management relationships to be formed within a group, the aim of which is to define complex and adaptive systems for the social life of a community [34]. Furthermore, a Sustainable Livelihood Framework (SLF) focuses on the interests of communities and recognizes the complexity of people's lives.

Therefore, the concept of community reveals the importance of finding ways of working together and collaborating; and, of course, a community provides a defined identity within the community that links its members around universes of meaning [35]. According to Willmott (1986), community means "having something in common", and, as this author stated, it is anchored in three elements: place, interest, and attachment [36]. That 
is, it involves a process aimed at improving living conditions with the available natural, social, human, physical, and financial resources [37].

A wealth of opportunities exists for tourist destinations with regard to agricultural food industries [38]. Properly managed agriculture, forestry, and aquaculture can provide nutritious food to the entire planet, as well as generate a decent income [12]. The agricultural sector is the world's largest employer and provides livelihoods for $40 \%$ of today's worldwide population [12]. As mentioned by the National Human Development Report [39], rurality can be defined as follows: "The response that is obtained from the relationships between the components: the territory as a source of natural resources, support of economic activities and the scenario of exchanges and political and cultural identities; the population that lives its life linked to natural resources and the earth and shares a certain cultural model".

Furthermore, in terms of tourism, positive food experiences encourage repeat visits [40]. For all of the above reasons, food tourism has the potential to revive regional gastronomies, food heritage, and special foodways, which, in turn, enhance residents' community pride and the authenticity of the tourist experience [41]. For many people, sustainable cultural tourism development is synonymous with CBT involving local people [42]. Indeed, at the start of this paper, we defined "community-based tourism" as a means of addressing pressing needs such as poverty alleviation [43], but it can also be understood as a business that is self-managed by communities (family groups, rural communities in the population of a region, cooperatives or indigenous villages), integrating this type of activity in a complementary way with the traditional activities carried out in rural areas [44].

In Mexico, the definitions of community tourism and indigenous tourism share a great similarity within the Indigenous Tourism Network, as tourism which is practiced in indigenous territories, with a focus on local culture, traditions, and customs [45]. Additionally, the indigenous peoples of the country have been able to protect the knowledge that has perpetuated their agrifood systems over time [14].

In fact, community-based tourism in Mexico has proliferated in contexts of indigenous and vulnerable populations with systems of communal land tenure [46]. Protecting an ecosystem also protects its native languages and cultures, as well as culinary heritage [47]. These indigenous peoples preserve languages and cultures rooted in the ecosystems and rhythms of their land [11].

Figure 1 shows destinations that highlight their gastronomic resources in the studied communities and some others positioned as the most representative within community and rural tourism at the gastronomic level in Mexico.

Figure 1 shows the gastronomic regions of Mexico in terms of communities and rural destinations where dishes and drinks receive tacit recognition in the international arena. The country's culinary wealth is also based on plurality and cultural roots, which has resulted in it occupying a relevant place in the world gastronomic scene [48].

The figure identifies the agave landscape and the old industrial facilities of Tequila. This was recognized as a cultural landscape by UNESCO in 1972 due to the production of cocoa and its route through Tabasco, Chiapas, Veracruz, and Oaxaca [49]. It is worth highlighting coffee production and destinations renowned for their culinary tradition and humanity heritage, such as Puebla and the State of Mexico, where the Tourism Office has launched the "Mesas Poblanas" program to bring together Puebla's best gastronomy, especially that of the historic center, which appears on the World Heritage List [50]. This initiative is made up of a selection of restaurants offering traditional Puebla cuisine. Finally, there are those destinations with specific traditional dishes such as "Tlayuda" in Oaxaca [51]. These are just a couple of examples of local actions aimed at developing tourism in rural destinations. 


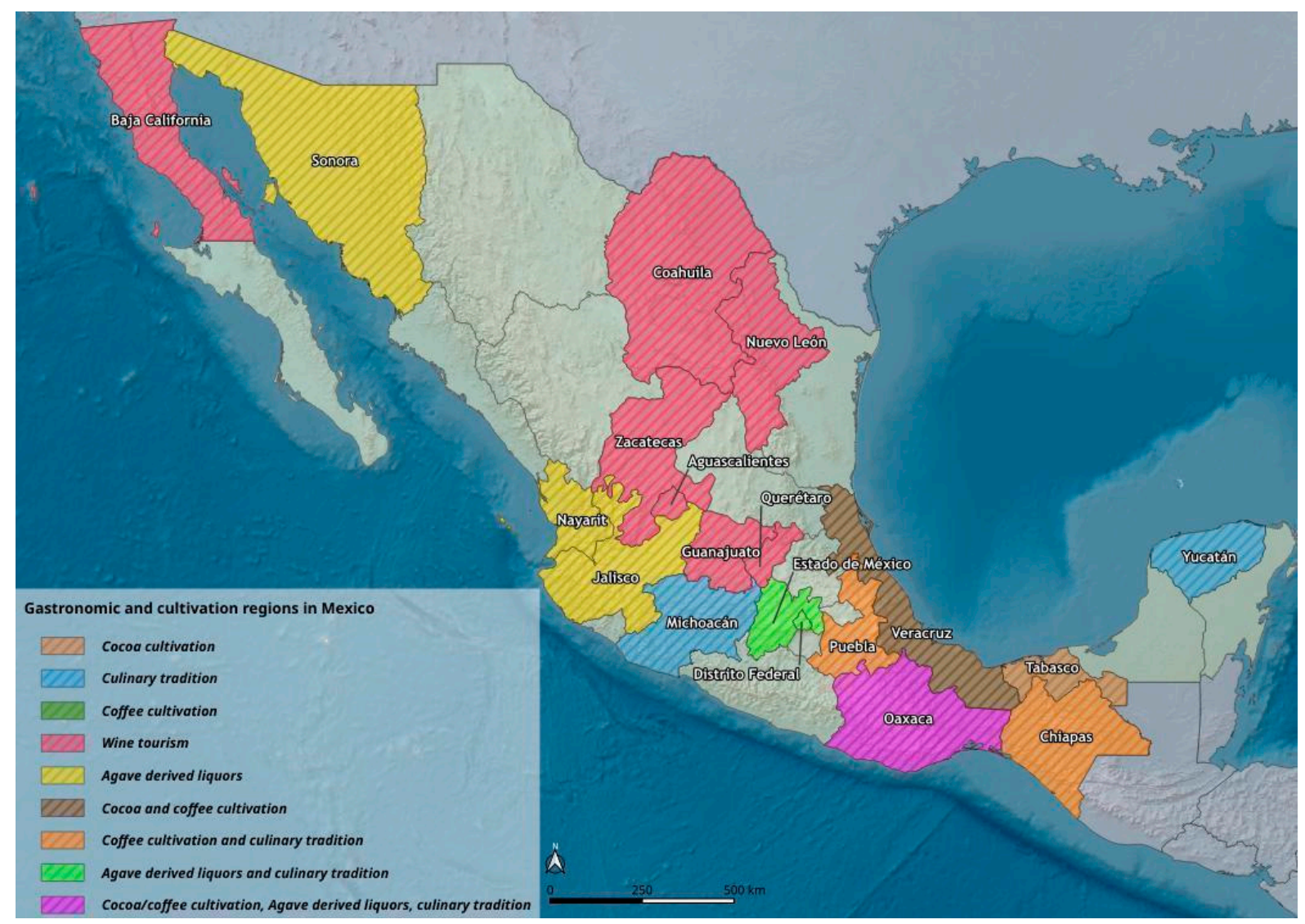

Figure 1. "Local gastronomic regions in Mexico". Source: authors; data-based tourist office in Mexico (2020).

Thus, CBT can be seen to foster productive ventures, with the community actively participating in the management of these and the profits being distributed in the local context. As a result of government action or self-managed community initiatives, there are currently 998 companies dedicated to advertising Mexico's alternative tourist services and activities, seven of them with indigenous participation. They are based in 729 locations, within 27 federal entities, and forming part of 414 municipalities, $16.82 \%$ of the total 2461 reported by the national municipal department [52].

Indigenous communities began developing tourism companies in Latin America almost three decades ago. This came about as a result of a combination of factors, including tourist activity becoming part of government policy following a rise in awareness regarding its relevance for development and the existence of a large wealth of natural resources present in the indigenous territories, which constitute an important attraction for new tourist activities [29,52].

Community-based tourism is notable for targeting the most disadvantaged sectors, allowing for an equitable distribution of income for regions in areas such as agriculture, heritage, and the environment [23]. Six dimensions are proposed for measuring the sustainability of CBT: political, social, ecological, economic, technological, and cultural indicators [53]. In this regard, the theory of "Government of the commons" [33] considers communities to be made up of individuals capable of reaching agreements and setting rules for the use of common resources. To sum up, community-based tourism seeks to promote the development of a community based on the collaborative work of its members. If we look at it from a Maslowian perspective, it can be seen as a pedagogical approach to the theory of self-actualization [7]. Furthermore, economic empowerment exists in a destination when jobs are created via tourism and result in regular, reliable, and lasting incomes for community members [54]. CBT therefore plays an important role in poverty alleviation by contributing to community development and sustainability [55]. 


\section{Materials and Methods: A Proposal of Indicators to Assess Sustainable CBT}

Different phases were designed to develop the indicators. The first consisted of a systematic revision of the literature and an analysis of different indicator systems. A systematic scoping review was employed to assess the literature on Sustainable Tourism Indicators with respect to four criteria, including the relevance of STIs to the SDGs, the role of local community participation as an important element of sustainability, the stakeholders involved, and the importance of local gastronomy in rural destinations in Mexico. This methodological proposal for a system of indicators is based on a bibliographic review, management models, and methodologies for the implementation of this sustainable development plan [56,57]. Other researchers have proposed a new indicator-based tool to assess the degree of progress and regress in tourism sustainability, the latter being an issue that is often ignored in indicator research [58]. Scoping reviews are increasingly more commonplace in the social sciences [57], including tourism [59], and are often used to provide an exploratory overview of a topic, map the literature, and identify key concepts, theories, and sources of evidence. They are most useful when an area is complex or has not yet been comprehensively reviewed [60]. This situation has far-reaching consequences with respect to tourism's contribution to sustainability, given the importance of appropriate indicators to effectively assess and manage tourism impacts $[8,61,62]$.

The present study reviewed articles focusing on sustainable tourism indicators and indices with which to measure the sustainability of rural and isolated destinations published in Scopus-indexed journals and Google Scholar up until December 2020. A keyword search was performed of the title, abstract, and keywords using the search term "sustainable tourism indicators." This initial search resulted in the identification of 945 articles. Another keyword search for food tourism indicator articles returned only 162 articles, while a third search with the keyword "sustainable food tourism indicator" resulted in 49 articles. In total, 1156 articles were identified in the three searches. This figure was reduced to 740 after eliminating duplicates. Selecting abstracts for their relevance to sustainable tourism indicators further reduced this figure to 120 . Finally, 92 journal articles were reviewed for this study.

The second phase consisted of the selection of indicators based on the different models identified in the previous phase. For the purposes of the present study, emphasis was placed on certain indicators specifically designed for CBT, and a set of sustainability indicator systems was analyzed to this end. Among the systems analyzed, the sets of indicators proposed by the following stand out: the World Tourism Organization [62], the Sustainable tourism program in Mexico [63], and the European Tourism Indicators System for Sustainable Tourism [64] together with some models proposed by academics [65-67]. Generally speaking, most of the indicator systems consider sustainability dimensions (sociocultural, environmental, tourism-related, and economic) and involve the participation of the local community subject of the study, as well as considering the views of other groups involved in the research.

The third phase was the validation of the indicators selected using different evaluation tools. Regardless of the number of indicators used, previous studies have strongly recommended a broad participation of key stakeholders during indicator development $[53,62,68,69]$.

This phase involved developing a questionnaire with questions related to tourism and the use of local products. For example: what is the importance of the participation of local communities in food production and the participation of different actors (agents, NGOs, etc.) in decision-making processes? Or the level of importance of the use of ancestral techniques and methods in the preservation and cooking of food? Or the perspective of the contribution of tourism to the destination's economy?

In total, 50 answers were collected, while 30 surveys were administered to groups of scholars specialized in tourism heritage, history, and sustainability. These scholars had been intentionally selected on the basis of their experience and knowledge. Professors in the Department of Tourism Studies at different universities in Ecuador, Spain, and Mexico were selected due to their geographic proximity to the study area and their experience in the 
subject under discussion. A total of 10 surveys were administered to leaders and experts in community-based tourism and entrepreneurs in gastronomic tourism in Mexico, including Komutravel, La Ruta del Origen, Turismo con Pao Sonora, Telar Social, and Agave Tourism, to mention a few. To ensure broad participation, 10 surveys were administered to tourists and local residents so that they could also participate in the evaluation process. The surveys were distributed using Google Forms during January and February 2021.

In addition to the survey, a series of interviews were conducted with different community tourism associations, including travel agencies, entrepreneurs, academics, and foundations in Mexico. These semi-structured interviews lasted approximately 30-45 min and an attempt was made to capture the diverse opinions of 10 actors consulted for this purpose. During these interviews, respondents were asked to see and share their comments on the primary purpose of indicators, and give their opinion on the importance of gastronomy in this rural destination and the development of tourism products related to CBT. These interviews were also conducted in January and February 2021.

Finally, the combination of qualitative (expert judgment) and quantitative (survey) methods allowed us to develop and validate the sustainability indicators [69]. Although 24 potential indicators were initially collected from the literature review, following the third phase, the list of indicators numbered 27, divided into four dimensions linking CBT development and gastronomy: socio-cultural, environmental, tourism, and economic. To explain and better understand the indicators proposed, different case studies have been analyzed for some of the regions presented in Figure 1.

The three case studies selected encompass the culinary tradition of Mexico. The first focuses on Ecatzingo, which is located in central Mexico and was affected by the 2017 earthquake, the epicenter of which was located at around $55 \mathrm{~km}$ (34 mi) south of the city. The earthquake caused damage in the Mexican states of Puebla, Morelos, and the State of Mexico. Ecatzingo is a rural destination located in the state of Mexico, and is home to much of the state's gastronomy, including the production of sausages, jams, honey, exotic stews, pulque, and other liquors. For the analysis conducted in this research, visits and interviews were carried out with local people and female cooks in Ecatzingo to discover the potential of the local gastronomy. The next case study was Michoacán, a city acknowledged as having UNESCO's Intangible Cultural Heritage of Humanity since 2010. Michoacán is considered the cradle of traditional Mexican cuisine. A literary review of Michoacán and its traditional gastronomy was considered necessary in order to conduct the analysis and validation. Thirdly, there are the regions where agave is grown, including places such as Jalisco, Sonora, State of Mexico, Nayarit, Oaxaca, and Mexico City. For the diagnosis and validation of indicators at these destinations, we enlisted the support of different travel agencies and foundations, including Komutravel and Agave Tourism.

\section{Results. Indicator Selection for Food Strategies in CBT}

In the literature review, the connection between food and community-based tourism has been explored. The authors propose a selection of indicators with the aim of proposing different indicators that allow a better understanding of this connection and the importance it may have in the sustainable development of vulnerable communities. Well-developed and properly validated sustainability indicators have an important role to play in assessing progress towards tourism sustainability, yet they are still missing in any real sense [70,71]. In this respect, sustainable tourism development is not easy to measure without breaking it down into smaller issues represented by indicators. Since there is no "one-size-fits-all" approach to assessing progress towards sustainable tourism development, devising a comprehensive methodology represents a huge challenge [70], and the first action by any country should be to measure its level of sustainability [72] using systematic and scientific methods of sustainability assessment [71].

With the above considerations in mind, the authors of this paper obtained a comprehensive list of sustainability indicators from an extended literature review and semistructured interviews with some key informants. 
Table 1 shows the final selection of indicators for assessing food strategies based on the research of the different authors mentioned, and the validation process involved in this research. The result is a list of 27 indicators, divided into four dimensions: socio-cultural, environmental, tourism, and economic. The socio-cultural dimension is related to human and social capital, while the environmental dimension relates to natural capital and the economic dimension focuses on financial capital. The tourism dimension has been added in order to assess the role that tourism can play in food strategies at the destination.

Table 1. Initial CBT indicators for assessing food strategies.

\begin{tabular}{|c|c|c|c|}
\hline Objectives & Indicator & Dimension & Description \\
\hline \multirow{7}{*}{$\begin{array}{l}\text { Professional skills and } \\
\text { abilities attributed to the } \\
\text { level of schooling, } \\
\text { training in community } \\
\text { tourism, food } \\
\text { production and } \\
\text { traditional knowledge. }\end{array}$} & \multirow{7}{*}{ Socio-cultural } & $\begin{array}{l}\text { 1. Existence of plans to protect food heritage or } \\
\text { food production. }\end{array}$ & $\begin{array}{l}\text { 1. Determine how many plans exist at the } \\
\text { destination for the protection of tangible and } \\
\text { intangible heritage, especially related to food and } \\
\text { traditional food production. }\end{array}$ \\
\hline & & $\begin{array}{l}\text { 2. Engagement of local communities in } \\
\text { food-producing and involvement of different } \\
\text { stakeholders in decision-making processes. }\end{array}$ & $\begin{array}{l}\text { 2. Quantify the participation of groups in different } \\
\text { actions and activities in their region. }\end{array}$ \\
\hline & & $\begin{array}{l}\text { 3. Traditional food knowledge (handcrafts, } \\
\text { recipes, gastronomy culture, ancestral methods) } \\
\text { (cultural heritage, tangible and intangible). }\end{array}$ & $\begin{array}{l}\text { 3. Evaluate the population's knowledge regarding } \\
\text { their traditions, traditional dishes and community. }\end{array}$ \\
\hline & & 4. Role of food traditions in social cohesion. & $\begin{array}{l}\text { 4. Determine the role of food as an element of social } \\
\text { cohesion (social events related to food, charity, etc.). }\end{array}$ \\
\hline & & 5. Employment in the food and tourism sectors. & $\begin{array}{l}\text { 5. Quantify the number of jobs related to food } \\
\text { production and related to tourism. }\end{array}$ \\
\hline & & $\begin{array}{l}\text { 6. Average salary of women in the tourism and } \\
\text { gastronomy industry. }\end{array}$ & $\begin{array}{l}\text { 6. Determine the role of women in the industry and } \\
\text { ascertain their salary. }\end{array}$ \\
\hline & & $\begin{array}{l}\text { 7. Recognition of women's work within the } \\
\text { community. }\end{array}$ & $\begin{array}{l}\text { 7. Determine the level of Recognition of women's } \\
\text { work within the community. }\end{array}$ \\
\hline \multirow{9}{*}{$\begin{array}{l}\text { Conservation actions } \\
\text { ancient recipes with } \\
\text { traditional vegetation. } \\
\text { Diversification of food } \\
\text { production. }\end{array}$} & \multirow{9}{*}{ Environmental } & 8. Level of community involvement in tourism & $\begin{array}{l}\text { 8. Identify the } \% \text { of community involvement in } \\
\text { tourism. }\end{array}$ \\
\hline & & 9.Use of local products in food preparation. & $\begin{array}{l}\text { 9.Determine origin of ingredients and food elements } \\
\text { (how much of food production comes from local } \\
\text { producers). }\end{array}$ \\
\hline & & 10. Use of endogenous seeds. & $\begin{array}{l}\text { 10. Identify how many endogenous seeds are used } \\
\text { in gastronomy. }\end{array}$ \\
\hline & & $\begin{array}{l}\text { 11. Level of biodiversity in seeds and } \\
\text { food-related elements. }\end{array}$ & $\begin{array}{l}\text { 11. Identify how many different species and seeds } \\
\text { there are in the local food traditions. }\end{array}$ \\
\hline & & 12. Use of ancestral techniques in agriculture. & $\begin{array}{l}\text { 12. Identify and list ancestral practices in } \\
\text { agriculture. }\end{array}$ \\
\hline & & $\begin{array}{l}\text { 13. Use of ancestral techniques and methods in } \\
\text { conservation and cooking of food. }\end{array}$ & $\begin{array}{l}\text { 13. Identify and list ancestral conservations and } \\
\text { cooking techniques. }\end{array}$ \\
\hline & & $\begin{array}{l}\text { 14. Use of renewable energies or techniques } \\
\text { respectful of the environment. }\end{array}$ & $\begin{array}{l}\text { 14. Identify best practices in agriculture with regard } \\
\text { to sustainability. }\end{array}$ \\
\hline & & $\begin{array}{l}\text { 15. Percentage of the region under a protection } \\
\text { plan (natural heritage). }\end{array}$ & $\begin{array}{l}\text { 15. Ascertain percentage of region covered by a } \\
\text { protection plan or declaration. }\end{array}$ \\
\hline & & 16. Regenerative community tourism agenda. & $\begin{array}{l}\text { 16. Identifying the destination has a regenerative } \\
\text { community tourism agenda. }\end{array}$ \\
\hline \multirow{7}{*}{$\begin{array}{l}\text { Loss of agricultural, } \\
\text { forest, wetlands, } \\
\text { infrastructure for } \\
\text { lodging, food and } \\
\text { equipment for tourists. }\end{array}$} & \multirow{7}{*}{ Tourism } & $\begin{array}{l}\text { 17. Infrastructure for hospitality managed by } \\
\text { local communities. }\end{array}$ & $\begin{array}{l}\text { 17. Determine percentage of hospitality } \\
\text { infrastructures (hostels, rooms, etc.) run by locals. }\end{array}$ \\
\hline & & $\begin{array}{l}\text { 18. Suppliers of restaurants or food } \\
\text { establishments run by local communities }\end{array}$ & $\begin{array}{l}\text { 18. Determine percentage of food-related services } \\
\text { run by locals. }\end{array}$ \\
\hline & & 19. Number of local tour guides. & $\begin{array}{l}\text { 19. Determine number of local tour guides } \\
\text { compared with external tour guides. }\end{array}$ \\
\hline & & $\begin{array}{l}\text { 20. Number of travel agencies, tour operators or } \\
\text { external agents involved in tourism activities. }\end{array}$ & $\begin{array}{l}\text { 20. Determine number of intermediaries in tourism } \\
\text { activities and conditions under which they operate } \\
\text { (percentage of benefits for locals). }\end{array}$ \\
\hline & & $\begin{array}{l}\text { 21. Percentage of tourists and visitors regarding } \\
\text { the local population }\end{array}$ & 21. Determine number of visitors per establishment. \\
\hline & & $\begin{array}{l}\text { 22. Average visitors per day, length of stay and } \\
\text { level of seasonality in tourism }\end{array}$ & $\begin{array}{l}\text { 22. Determine main visitor traits, especially } \\
\text { regarding seasonality. }\end{array}$ \\
\hline & & $\begin{array}{l}\text { 23. Percentage of tourists that are satisfied with } \\
\text { the visit and experience in the local community }\end{array}$ & $\begin{array}{l}\text { 23. Determine tourists' level of satisfaction } \\
\text { regarding the experience they have with locals. }\end{array}$ \\
\hline
\end{tabular}


Table 1. Cont.

\begin{tabular}{|c|c|c|c|}
\hline Objectives & Indicator & Dimension & Description \\
\hline \multirow{4}{*}{$\begin{array}{l}\text { Economic resources of } \\
\text { the organization. } \\
\text { Employment and job } \\
\text { opportunities for the } \\
\text { community. }\end{array}$} & \multirow{4}{*}{ Economic } & 24. Changes in land tenure. & $\begin{array}{l}\text { 24. Identify changes in land tenure caused by } \\
\text { tourism activities. }\end{array}$ \\
\hline & & 25. Capital for reinvestment. & $\begin{array}{l}\text { 25. Identify where income from tourism is spent and } \\
\text { level of reinvestment in activities supporting the } \\
\text { community. }\end{array}$ \\
\hline & & $\begin{array}{l}\text { 26. Contribution of tourism to the destination's } \\
\text { economy. }\end{array}$ & $\begin{array}{l}\text { 26. Determine the importance of tourism as } \\
\text { economic activity among all economic activities in } \\
\text { the community. }\end{array}$ \\
\hline & & $\begin{array}{l}\text { 27. Daily spending per tourist in local } \\
\text { communities (accommodation, food, handcrafts } \\
\text { not in intermediaries or external companies). }\end{array}$ & $\begin{array}{l}\text { 27. Determine the average expenditure per tourist in } \\
\text { the community, without considering the money } \\
\text { spent on intermediaries or other companies outside } \\
\text { the community }\end{array}$ \\
\hline
\end{tabular}

Source: authors' data based on different indicators systems $[16,63,66,67]$.

The proposed system is based on four dimensions of indicators: socio-cultural, environmental, tourism and economic.

\subsection{Socio-Cultural Indicators}

Socio-cultural indicators reflect the knowledge of the local population regarding the culinary culture itself, at the level of recipes, traditions, methods of food production and conservation, etc. For example, Indicators 1, 3, and 4 (Table 1) refer to food preservation and tradition. These indicators are supported by the fact, for example, that Michoacán has a UNESCO gastronomic heritage protection plan. Throughout Figure 1 and the literature review, this destination is considered the cradle of traditional cuisine; currently, there are more than 80 traditional cooks in the area, from regions such as Tierra Caliente, the Lacustrine Zone, the Coast Region, the East Region, the West Zone, and the Morelia Region. They are dedicated to preserving the traditional flavors originating in the state [48], and rural communities can benefit from the marketing of local products [28]. Likewise, the places where agave is grown, specifically for the Tequila in Jalisco, the Bacanora in Sonora, and the Mezcal in Oaxaca, validate this same indicator as it is a Designation of Origin product with a protection plan for culinary heritage [41]. Furthermore, in the case of Ecatzingo, the result of applying this indicator shows that the site does not have an official heritage protection plan; however, the community is commited to food sovereignty as they decide on their own agricultural, labor, fisheries, food and land policies.

On the other hand, Indicators 2, 6, and 7 (Table 1) refer to the "Recognition of women's work within the community". In the case sudy of Ecatzingo, it was easier to apply this indicator using the number of food establishments there that are run by women-which was less than the average; the results of the interviews conducted at this destination revealed that women have the role of housewife and little access to work. An opposite example is found in the case of Michoacán, where a high recognition of women's role and work is payed by UNESCO, and most of the establishments and recipes pertain to the female population. Finally, with regard to places that produce agave, recognition for women is low according to the interview done with Komutravel, since most of those who promote and work within this area are men.

\subsection{Environmental Indicators}

As for environmental indicators, they reflect the importance of the agroecosystem's ecological diversity with regard to developing agriculture, feeding, and the multiple forms of adaptation coexisting therein [14].

The environment plays a very important role in sustainable development. In the area of food-related indicators, it is important to take into account the relationship established between the means of food production and sustainable development. As our review of the literature shows, SDG 2 is related to food, and some of the topics mentioned are the promotion of small farms, the recovery of traditional techniques, and the application 
of techniques that are respectful of the environment. The proposed indicators should determine the number of local products used in the kitchen and identify the methods employed to produce them.

By way of example for Indicator 9 (Table 1), the interview with Armando Vazquez from "Agave Tourism" contributed information from the case of Zacazonapan, a municipality in the State of Mexico, where mature cheese production is a traditional activity that has been carried out for over 150 years. Its continuity is at risk today because the producers are older women and young people are not interested in maintaining it. The proposed indicators can be used to identify practices such as this and develop a proposal for heritagization. The aim here would be to relaunch this productive activity, which represents a contribution not only to the family but also the local and regional economies [73].

Indicators 11,14, 15, and 16 (Table 1) can help in the development of plans for protecting the environment and achieving sustainable development at the site without damaging it, as also mentioned in the following UN SDGs: 8 (inclusive and sustainable economic growth), 12 (sustainable consumption and production), and 14 (sustainable use of oceans and marine resources) [6]. In the three case studies evaluated, Michoacán displayed active participation in terms of intangible gastronomic care, but not in destination sustainability, while Ecatzingo - through its regional government-has plans to ensure protection of the soil and regeneration of the environment, and the same is true in those regions where agave is planted.

\subsection{Tourism Indicators}

This indicator highlights the importance of using food heritage as a strategy to improve the competitiveness of local tourist activity and, at the same time, strengthen the identities and cultural traits of rural groups. In this case, it is important to quantify the number of restaurants and accommodation establishments in vulnerable destinations, in order that communities be properly developed through sustainable tourism. As the indicators show, it is also necessary to focus on evaluating land tenure and changes in this, in order to generate tourism experiences that do not affect the environment. Equal importance should be given to quantifying the intangible and natural heritage of a vulnerable tourist destination in order to make it sustainable, taking into account all the tourist attractions and the potential of the evaluated community.

Indicators 21, 22, and 23 refer to "average visitors per day". Although these data are available, in some cases it is only at the national level and, in some cases, the regional level, but very rarely at the municipal level. Other issues are related to the origin of tourists. However, the lack of data for municipalities or even regions is an obstacle in this regard.

With regard to gastronomy, Indicator 18, "suppliers of restaurants or food establishments managed by local communities", the main problem is that there is no database available in most cases, so data must be collected by contacting each individual rural destination. Generally speaking, for the three case studies here, we find more local establishments than foreign ones, due to the isolated and/or rural location of the destinations.

\subsection{Economic Indicators}

Isolated and rural communities face different challenges, and sustainability is one of them. In most cases, when it comes to vulnerable communities, sustainability is about how to maintain traditions and how to survive. The information collected using this system of indicators should allow for a diagnosis of the destination, highlighting the strengths and threats in developing the community.

With indicators 26 and 27, for example, "daily spending per tourist in local communities (accommodation, food, handcrafts not in intermediaries or external companies)," it is particularly interesting to determine tourists' daily expenditure and the level of employment in the rural destination. This can be especially useful if it is comparable between rural and isolated areas. However, it is difficult to obtain data disaggregated by municipalities 
or regions, and adaptation or customization for rural areas is therefore not possible in most cases.

An example of the above can be found in a long-term project underway in Sonora (Agave Case), which aims to promote the Sierra Alta de Sonora by creating a gastronomic route through the region [74]. The research carried out here shows that these routes may benefit small producers in the region and restaurants in the community, as well as sales by typical food and street vendors. However, there is a lack of an institutional and community gastronomic tourism inventory [75], and this makes it difficult to identify traditional practices and the preservation actions that should be undertaken.

During the interviews and surveys, as well as being asked about the different indicators, respondents were also asked to identify those areas or indicators that they considered most important for the sustainable development of their community. Figure 2 shows the results obtained. Indicators were scored based on a scale of three levels (low, medium, and high), taking the difference between the four dimensions as a basis.

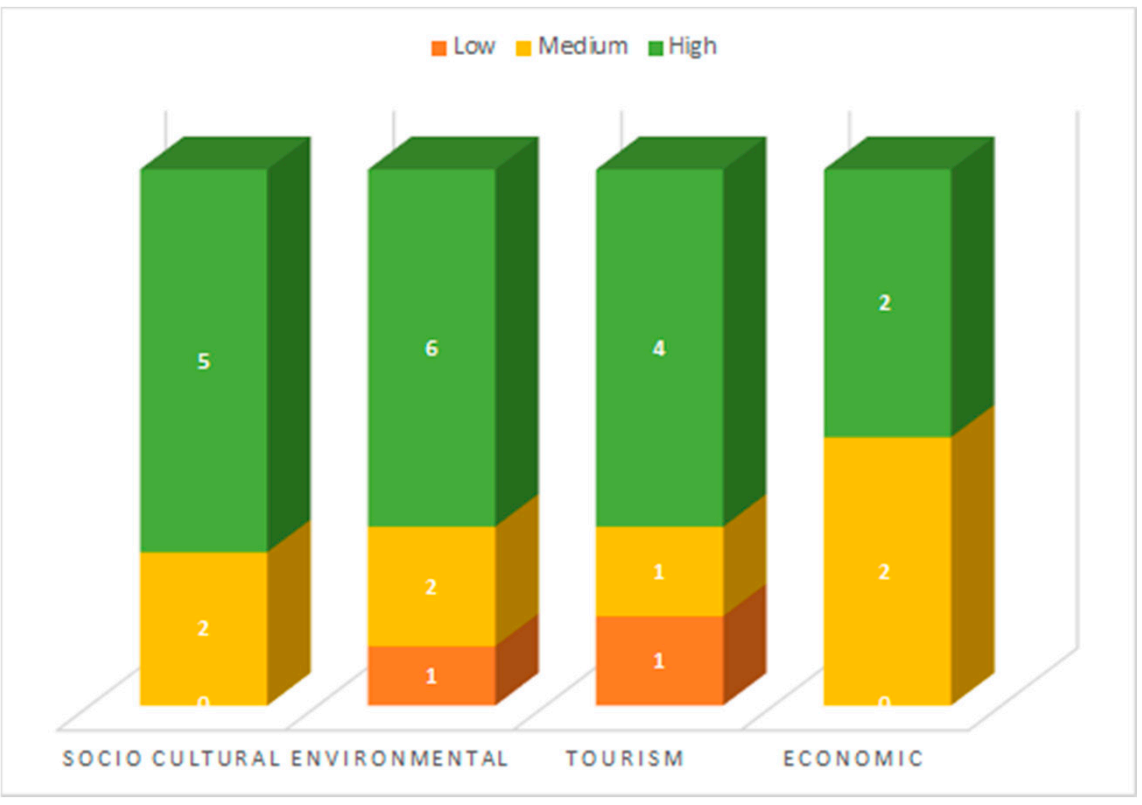

Figure 2. Level of importance Sustainable Tourism Indicator. Source: authors' own work.

As can be observed in Figure 2, the socio-cultural and environmental dimensions are considered to be most important, with five and six indicators, respectively, while the economic dimension is considered to be less relevant. According to the respondents, the dimensions that have more weight in decision-making and strategies in rural destinations are the socio-cultural and environmental dimensions.

As for which indicators are considered to be most relevant, in the socio-cultural dimension we find Indicators 1, 3, 4, 6, and 7 (Table 1). Indicators 1, 3, and 4 refer to the role food has in the preservation of local traditions and the tools available to protect this knowledge. Indicators 6 and 7 refer to the role played by women, considered fundamental as keepers of food knowledge in most of the communities analyzed. As for the environmental dimension, the selected indicators were 8, 9, 12, 13, 14, and 15 (Table 1). Indicators 9, 12, and 13 are related to the use of local food and traditional techniques in agriculture and food production, which are also closely related to the socio-cultural dimension.

\section{Conclusions and Discussion}

This systematic review of the research literature and validation of indicators has focused on the following aspects: the relevance of STIs to the UN's SDGs, the role of local community participation as an important element of sustainability, the actors involved, and the importance of local gastronomy in rural destinations. To effectively develop 
and implement sustainability metrics for tourism, it may be necessary to provide new opportunities in destinations for actors who may previously have been excluded from the policy process [8]. A further aim of this article has been to develop and validate sustainability indicators that might help monitor tourism activity and its impacts. As mentioned above, subjective indicators refer to the opinions of actors, academic groups, and travel agencies, as well as tourists' experiences, perceptions, and satisfaction levels; these indicators refer to the context of Mexico. A participatory and systematic approach has been followed, and the results show how it is possible to develop and validate very useful sustainability indicators.

In many places where agave is grown, the locals make distillates of tequila, mezcal, and bacanora. As Figure 1 shows, the label "Agave production" is widespread throughout the gastronomic regions of Mexico. With regards to Table 1, the economic and tourist dimensions show a wide contribution of tourism to destinations' economies through promotion by travel agencies, products offered by local restaurants and local tourist guides, and the role played by food traditions in the social cohesion of these regions. In fact, in many areas, such as Tequila in Jalisco or Bacanora in Sonora, these culinary traditions represent an identity and the Denomination of Origin product stands out in developing gastronomic tourism for the entire country.

Also, in relation to the socio-cultural, tourism, and economic dimensions, there are several ways in which a solid gastronomic identity can be created and maintained as a way of promoting tourist destinations [4]. These are differentiation, authentication, and aestheticization (playing with emotions, pleasures, desires, and moods). Complementary activities such as agritourism have now also emerged due to people's need to relive memories of earlier times spent on a farm, picking and eating the wholesome foods of their youth [20]. Thus, the aim of tourism indicators is to identify the weight of food-tourism strategies in a community's tourism plans.

The above notwithstanding, it is important to bear two things in mind. First, vulnerable communities face challenges in devising a proper sustainability-oriented plan, and need to avoid damaging the quality of life of their inhabitants, a loss of heritage, negative economic impacts, and environmental degradation. Second, sustainable tourism can be achieved through food sovereignty and cuisine heritage, a process that requires the interest and constant participation of government administrations and the private sector.

This review provides a platform to potentially help policymakers, businesses, and researchers to better understand how gastronomy tourism indicators can be used to address the UN's SDGs on various scales within a common approach, but one that targets isolated and vulnerable destinations. Researchers must also address the relationships existing between the different modes of governance within Mexico and the development of indicators, as well as the monitoring and evaluation process.

In the case of isolated and vulnerable destinations in Mexico, such as Ecatzingo or Zacazonapan in the State of Mexico, which have a very low level of tourism and are not easily accessible, this article has shown that it is possible to develop indicators at the national level for rural and isolated destinations. These, in turn, have a broad gastronomic diversity and natural resources in their environment, promoting sustainable development and potential tourism trade for the local community.

This study makes some important contributions. First, it is necessary to mention the contribution of Figure 1, which shows the gastronomic resources in rural communities of Mexico. Desite the high levels of gastronomic tourism, there is little clarity on where to find it and how to identify it. This study therefore makes a small contribution to identifying and highlighting the gastronomic areas of Mexico in rural and isolated spaces. By way of example, the country's official tourism website only highlights the alternative tourism regions in Mexico, and a small section on "where to eat in Mexico". It was therefore necessary to compile a map to highlight these forgotten destinations. Second, it is worth mentioning the participation of numerous actors, including university professors from three universities (in Mexico, Spain, and Ecuador), tourists, local residents, and directors and experts 
from the offices of culture and tourism. Third, unlike most previous research, this study has considered the local gastronomy framework in the process of developing indicators. Carefully refined and developed indicators can bridge the gap between information and action $[62,76]$. Finally, this study takes the existing literature on tourism sustainability as a starting point and adds new approaches derived from community tourism and its relationship with gastronomy. Identifying the problems and areas where action is most urgently needed would prove a thankless task without using well-developed and validated sustainability indicators. Despite its limitations, this study introduces the local gastronomic approach to isolated regions of Mexico, based on the premise that well-developed indicators will help detect sustainability problems in rural destinations.

Author Contributions: Conceptualization, M.S., Data curation, S.A.; Methodology, M.S. and S.A.; Resources, M.S.; Supervision L.M.; Writing-original draft, M.S.; Writing-review \& editing S.A. and L.M. All authors have read and agreed to the published version of the manuscript.

Funding: Not applicable.

Institutional Review Board Statement: Not applicable.

Informed Consent Statement: Informed consent was obtained from all subjects involved in the study.

Data Availability Statement: The data will be made available on request from the corresponding author.

Conflicts of Interest: The authors declare no conflict of interest.

\section{References}

1. Ruhanen, L. Local government: Facilitator or inhibitor of sustainable tourism development? J. Sustain. Tour. 2013, 21, 80-98. [CrossRef]

2. Koretskaya, O.; Feola, G. A framework for recognizing diversity beyond capitalism in agri-food systems. J. Rural. Stud. 2020, 80, 302-313. [CrossRef]

3. Haghebaert, B. Working with vulnerable communities to assess and reduce disaster risk. Humanit. Exch. 2007, $38,15-16$.

4. Timothy, D.J.; Ron, A.S. Heritage cuisines, regional identity and sustainable tourism. In Sustainable Culinary Systems: Local Foods, Innovation, and Tourism E Hospitality; Routledge: London, UK, 2013; pp. 275-290.

5. Alarcon, O.A.; González, H.E. El desarrollo económico local y las teorías de localización. Revisión teórica. Rev. Espac. 2018, 39, 4.

6. Tourism and the Sustainable Development Goals_Journey to 2030; UNWTO: Madrid, Spain, 2017.

7. Maslow, A.H. A Theory of Human Motivation. Psychol. Rev. 1943, 50, 370-396. [CrossRef]

8. Rasoolimanesh, S.M.; Ramakrishna, S.; Hall, C.M.; Esfandiar, K.; Seyfi, S. A systematic scoping review of sustainable tourism indicators in relation to the sustainable development goals. J. Sustain. Tour. 2020, 1-21. [CrossRef]

9. Holling, C.S. Understanding the Complexity of Economic, Ecological, and Social Systems. Ecosystems 2001, 4, 390-405. [CrossRef]

10. Pardo, J. La cultura: factor de desarrollo, prosperidad y felicidad. Fundacciones. Revista de Acción Cultural. $2009,7,1$.

11. Pigem, J. GPS (Global Personal Social). Valores Para un Mundo en Transformación; Editorial Kairós: Barcelona, Spain, 2011.

12. United Nations. Sustainable Development Goals: Goal 2 Zero Hunger. Available online: https://www.un.org/sustainabledevelo pment/hunger/ (accessed on 21 September 2020).

13. Higgins, V.; Dibden, J.; Cocklin, C. Building alternative agri-food networks: Certification, embeddedness and agri-environmental governance. J. Rural Stud. 2008, 24, 15-27. [CrossRef]

14. Lugo-Morin, D.R. Indigenous communities and their food systems: A contribution to the current debate. J. Ethn. Foods 2020, 7, 1-10. [CrossRef]

15. Damman, S.; Eide, W.B.; Kuhnlein, H.V. Indigenous peoples' nutrition transition in a right to food perspective. Food Policy 2008, 33, 135-155. [CrossRef]

16. Ortega Cerdà, M.; Rivera-Ferre, M.G. Indicadores internacionales de Soberanía Alimen-taria: Nuevas herramientas para una nueva agricultura. Revibec 2010, 14, 53-77.

17. Echánove, F.; Steffen, C. Agribusiness and farmers in Mexico: The importance of contractual relations. Geogr. J. 2005, 171, 166-176. [CrossRef]

18. Aulet, S.; Mundet, L.; Roca, J. Between Tradition and Innovation: The Case of El Celler De Can Roca. J. Gastron. Tour. 2016, 2, 135-149. [CrossRef]

19. Torres, J.M.M.; de la Fuente, G.M.C. Traditional Regional Cuisine as an Element of Local Identity and Development: A Case Study from San Pedro El Saucito, Sonora, Mexico. J. Southwest 2012, 54, 599-620. [CrossRef]

20. Curtis, K.; Slocum, S. Farm Diversification through Farm Shop Entrepreneurship in the UK. J. Food Distrib. Res. 2017, 48, 35-51.

21. Stalder, F.; Hirsh, J. Open Source Intelligence. First Monday 2002, 7. [CrossRef] 
22. Mondino, E. Strengthening the Link Between Conservation and Sustainable Development: Can Ecotourism Be a Catalyst? The Case of Monviso Transboundary Biosphere Reserve, Italy. Master's Thesis, Uppsala University, Uppsala, Sweden, 2017.

23. Gascón, J.; Cañada, E. Viajar a Todo Tren: Turismo, Desarrollo y Sostenibilidad; Icaria: Barcelona, Spain, 2005.

24. Leadbeater, B. How disability studies and ecofeminist approaches shape research: Exploring small-scale farmer perceptions of banana cultivation in the Lake Victoria region, Uganda. Disabil. Glob. South 2017, 2, 752-776.

25. Wolf, E. Culinary tourism-a hot and fresh idea. TourismReview. com. 5-6 December 2008. Available online: https://www.touris m-review.com/travel-tourism-magazine-culinary-tourism-a-hot-and-fresh-idea-article677 (accessed on 20 October 2020).

26. Boniface, P. Tasting Tourism: Travelling for Food and Drink; Routledge: London, UK, 2017. [CrossRef]

27. Scheidel, A. New Challenges in Rural Development a Multi-Scale Inquiry Into Emerging Issues, Posed by the Global Land Rush. Ph.D. Thesis, Universitat Autònoma de Barcelona, Barcelona, Spain, 2013.

28. Sidali, K.L.; Kastenholz, E.; Bianchi, R. Food tourism, niche markets and products in rural tourism: Combining the intimacy model and the experience economy as a rural development strategy. J. Sustain. Tour. 2013, 23, 1179-1197. [CrossRef]

29. Timothy, D.J. Cultural Heritage and Tourism: An Introduction; Channel View Publications: Bristol, UK, 2011 ; Volume 4.

30. Aulet, S.; Mundet, L.; Vidal, D. Monasteries and tourism: Interpreting sacred landscape through gastronomy. Rev. Bras. Pesqui. Turismo 2017, 11, 175-196. [CrossRef]

31. Halldórsdóttir, P.Ó.; Nicholas, K.A. Local food in Iceland: Identifying behavioral barriers to increased production and consumption. Environ. Res. Lett. 2016, 11, 115004. [CrossRef]

32. Forson, P.W.; Counihan, C. (Eds.) Taking Food Public: Redefining Foodways in a Changing World; Routledge: London, UK, 2013.

33. Ostrom, E. El Gobierno de los Bienes Comunes: La Evolución de las Instituciones de Acción Colectiva; No. E14-295; UNAM-CRIM-FC: Cuernavaca, Mexico, 2009; ISBN 978-968-16-6343-8.

34. Durston, J. ¿ Que es el Capital Social Comunitario? Cepal: Santiago, Chile, 2000.

35. Young, M.; Cohen, A.P. The Symbolic Construction of Community. Man 1988, 23, 570. [CrossRef]

36. Ruiz-Ballesteros, E. Social-ecological resilience and community-based tourism: An approach from Agua Blanca, Ecuador. Tour. Manag. 2011, 32, 655-666. [CrossRef]

37. Laverack, G.; Thangphet, S. Building community capacity for locally managed ecotourism in Northern Thailand. Community Dev. J. 2007, 44, 172-185. [CrossRef]

38. Hall, C.M.; Scott, D.; Gössling, S. The primacy of climate change for sustainable international tourism. Sustain. Dev. 2013, 21, 112-121. [CrossRef]

39. United Nations. Human Development Report 2011. Sustainability and Equipty. A Better Future for All. 2011. Available online: http:/ /hdr.undp.org/sites/default/files/reports/271/hdr_2011_en_complete.pdf (accessed on 5 December 2020).

40. Sparks, B.A.; Bowen, J.T.; Klag, S. Restaurants and the tourist market. Int. J. Contemp. Hosp. Manag. 2003, 15, 6-13. [CrossRef]

41. Kim, S.; Park, E.; Lamb, D. Extraordinary or ordinary? Food tourism motivations of Japanese domestic noodle tourists. Tour. Manag. Perspect. 2019, 29, 176-186. [CrossRef]

42. Lamers, M. Between protection and progress: An actor oriented approach to cultural tour-ism development in Kenya. Ph.D. Thesis, Maastricht University, Maastricht, The Netherlands, 2001.

43. Knight, D.W.; Cottrell, S.P. Evaluating tourism-linked empowerment in Cuzco, Peru. Ann. Tour. Res. 2016, 56, 32-47. [CrossRef]

44. van der Ploeg, J.D. Camponeses e Impérios Alimentares; Lutas por Autonomia e Sustentabilidade na era da Globalicação; UFRGS Editora: Porto Alegre, Brazil, 2008.

45. RITA, Red Indígena de Turismo de México. 2010. Available online: http:/ / www.rita.com.mx/ (accessed on 10 December 2020).

46. Patel, L.; Kaseke, E.; Midgley, J. Indigenous welfare and community-based social development: Lessons from African innovations. J. Community Pract. 2012, 20, 12-31. [CrossRef]

47. Battiste, M.; Youngblood, J. Protecting Indigenous Knowledge and Heritage: A Global Challenge; UBC Press: Vancouver, BC, Canada, 2000.

48. SECTUR: Gastronomía Mexicana. 2014. Available online: http://www.sectur.gob.mx/blog-de-lasecretaria/2014/09/05/gastro nomia-mexicana/ (accessed on 9 January 2021).

49. UNESCO (n.d.). Cultural Landscapes. Available online: https://whc.unesco.org/en/culturallandscape/ (accessed on 9 January 2021).

50. Treserras, J. El efecto turístico de los sellos UNESCO relacionados con la gastronomía en el espacio cultural Iberoamericano. In Gastronomia y Turismo; CIET: Buenos Aires, Argentina, 2017; pp. 15-28.

51. Santiago-Mejía, B.E.; Martínez-Menez, M.R.; Rubio-Granados, E.; Vaquera-Huerta, H.; Sánchez-Escudero, J. Variabilidad espacial de propiedades físicas y químicas del suelo en un sistema la-ma-bordo en la Mixteca Alta de Oaxaca, México. Agric. Soc. Desarro 2018, 15, 275-288.

52. Palomino Villavicencio, B.; Gasca Zamora, J.; López Pardo, G. El turismo comunitario en la Sierra Norte de Oaxaca: Perspectiva desde las instituciones y la gobernanza en territorios indígenas. El Periplo Sustentable 2016, 6-37.

53. Choi, H.C.; Sirakaya, E. Sustainability indicators for managing community tourism. Tour. Manag. 2006, 27, 1274-1289. [CrossRef]

54. Scheyvens, R. Ecotourism and the empowerment of local communities. Tour. Manag. 1999, 20, 245-249. [CrossRef]

55. Lee, T.H.; Jan, F.H. Can community-based tourism contribute to sustainable development? Evidence from residents' perceptions of the sustainability. Tour. Manag. 2019, 70, 368-380. [CrossRef] 
56. Grant, M.J.; Booth, A. A typology of reviews: An analysis of 14 review types and associated methodologies. Health Inf. Libr. J. 2009, 26, 91-108. [CrossRef] [PubMed]

57. Moher, D.; Shamseer, L.; Clarke, M.; Ghersi, D.; Liberati, A.; Petticrew, M.; Shekelle, P.; Stewart, L.A. Ítems de referencia para publicar Protocolos de Revisiones Sistemáticas y Metaanálisis: Declaración PRISMA-P 2015. Rev. Española Nutr. Hum. Dietética 2015, 20, 148-160.

58. Blancas, F.; Lozano, M.G.; González, M.; Caballero, R. Sustainable tourism composite indicators: A dynamic evaluation to manage changes in sustainability. J. Sustain. Tour. 2016, 24, 1403-1424. [CrossRef]

59. Seyfi, S.; Hall, C.M. Sanctions and tourism: Effects, complexities and research. Tour. Geogr. 2019, 22, 749-767. [CrossRef]

60. Lukersmith, M.S.; Millington, M.; Salvador-Carulla, L. What is case management? A scoping and mapping review. Int. J. Integr. Care 2016, 16, 2. [CrossRef] [PubMed]

61. Torres-Delgado, A.; Palomeque, F.L. Measuring sustainable tourism at the municipal level. Ann. Tour. Res. 2014, 49, 122-137. [CrossRef]

62. Indicators of Sustainable Development for Tourism Destinations: A Guidebook; World Tourism Organization: Madrid, Spain, 2004; Available online: http:/ / sdt.unwto.org/sites/all/files/docpdf/finalreport-bohol2008.pdf (accessed on 13 January 2021).

63. SECTUR Sustainable tourism program in Mexico. 2013. Available online: https://www.gob.mx/sectur (accessed on 15 December 2020).

64. European Commission. The European Tourism Indicator System. ETIS Toolkit for Sustainable Destination Management; European Union: Luxembourg, 2016.

65. Hanai, F.Y. Sistema de indicadores de sustentabilidade: uma aplicação ao contexto de desenvolvimento do turismo na região de Bueno Brandão, Estado de Minas Gerais, Brasil. Ph.D. Thesis, Universidade de São Paulo, São Paulo, Brazil, 2009.

66. Chambers, R.; Conway, G. Sustainable Rural Livelihoods: Practical Concepts for the 21st Century; Institute of Development Studies: Brighton, UK, 1992.

67. Carrillo García, M.; Enríquez Rocha, P.; Meléndez Herrada, A. Gestión comunitaria y potencial del aviturismo en el Centro de Ecoturismo Sustentable El Madresal, Chiapas, México. El Periplo Sustentable 2017, 564-604.

68. OECDiLibrary. Health at a Glance 2015: OECD Indicators; OECD Publishing: Paris, France, 2015; Available online: https:/ / www.oe cd-ilibrary.org/social-issues-migration-health/health-at-a-glance-2015_health_glance-2015-en (accessed on 25 November 2020).

69. Asmelash, A.G.; Kumar, S. Assessing progress of tourism sustainability: Developing and validating sustainability indicators. Tour. Manag. 2019, 71, 67-83. [CrossRef]

70. Cernat, L.; Gourdon, J. Paths to success: Benchmarking cross-country sustainable tourism. Tour. Manag. 2012, 33, 1044-1056. [CrossRef]

71. Ko, D.-G.; Kirsch, L.J.; King, W.R. Antecedents of Knowledge Transfer from Consultants to Clients in Enterprise System Implementations. MIS Q. 2005, 29, 59. [CrossRef]

72. Pulido-Fernández, J.I.; Andrades-Caldito, L.; Sánchez-Rivero, M. Is sustainable tourism an obstacle to the economic performance of the tourism industry? Evidence from an international empirical study. J. Sustain. Tour. 2015, 23, 47-64. [CrossRef]

73. Osorio González, R.; Serrano Barquín, R.D.C.; Palmas Castrejon, Y.D. Patrimonialización y patrimonio inmaterial como elemento dinamizador de la economía local en Zacazonapan, Estado de México. Int. J. Sci. Manag. Tour. 2018, 4, 409-434.

74. Bringas, O. Rutas alimentarias. Identificación de elementos básicos para su creación en la sierra alta de Sonora. Tesis de maestría en Promoción y Desarrollo Cultural. Doctoral Dissertation, Universidad Autónoma de Coahuila, Hermosillo, Mexico, 2010.

75. Salido Araiza, P.; Banuelos Flores, N.; Romero Escalante, D.M.; Romo Paz, E.L.; Ochoa Manrique, A.I.; Rodica Caracuda, A.; Cervantes, O. El patrimonio natural y cultural como base para estrategias de turismo sustentable en la Sonora rural. Estud. Soc. 2010, 17, 79-103.

76. Twining-Ward, L.; Butler, R. Implementing STD on a Small Island: Development and Use of Sustainable Tourism Development Indicators in Samoa. J. Sustain. Tour. 2002, 10, 363-387. [CrossRef] 